\title{
Investigating local regulation of the testes of ruminants
}

\author{
S. Maddocks, S. Kern and B. P. Setchell \\ Department of Animal Science, University of Adelaide, Waite Agricultural Research Institute, \\ Glen Osmand, South Australia 5064
}

\begin{abstract}
In addition to endocrine regulation by the gonadotrophic hormones, the functions of the testes are regulated locally by paracrine and autocrine factors. Some attempts have been made to isolate cells from the testes of immature bulls and rams for investigation of cell function in vitro. However, most studies have used in vitro cultures of cells isolated from the testes of rats and a large variety of factors have been identified as potential local regulators. This review examines the importance of Sertoli cell-germ cell interactions, Leydig cells and steroidogenesis, blood flow and vascular permeability, and cytokines and immune cells as local regulators of the testes. The small amount of work undertaken on the testes of ruminants is reviewed together with approaches such as the transilluminated dissection of staged seminiferous tubules and in vivo cell depletion models used with rats. The suitability and limitation of these approaches for ruminants are considered, and immunological and molecular probes are raised as options for future investigations of the local regulation of the testes of ruminants.
\end{abstract}

\section{Introduction}

Although endocrine regulation of the testes is important in ensuring that reproductive processes are synchronized with physiological events such as puberty, or with environmental changes, such as season or nutrition, it is becoming increasingly apparent that it is the local regulation that occurs within the testes that holds the key to fertility and male reproductive performance.

Most work on local regulation in the testes has focused on the seminiferous epithelium because of its role in producing spermatozoa. What distinguishes the testes from many other organs where local regulation occurs is the need to maintain the continuous, cyclical processes of the multiplication and differentiation of germ cells to produce spermatozoa. When the testis is viewed in cross-section, seminiferous tubules are seen to contain different groups or cohorts of various germ cells at different stages of maturation, and this reflects the different stages of the spermatogenic cycle; each germ cell is usually associated with a specific group of other germ cells. In rams, eight such associations or stages can be identified, with 12 in bulls and 14 in rats (Hochereau-de Reviers et al., 1990; Fig. I). The implication of these consistent associations is that there must be a tightly regulated process of local co-ordination within the seminiferous epithelium.

\section{Sertoli Cell-Germ Cell Interactions}

The Sertoli cell has long been recognized as the likely principal regulator of the seminiferous epithelium. It forms tight junctions with adjacent Sertoli cells to create the blood-testis barrier that provides the unique microenvironment within the seminiferous tubule to support the developing germ cells. It maintains an intimate association with the germ cells that are embedded into the folds of its cell membrane, and the notion of the Sertoli cell as a nurse cell providing the nutritional needs and structural 
(a)

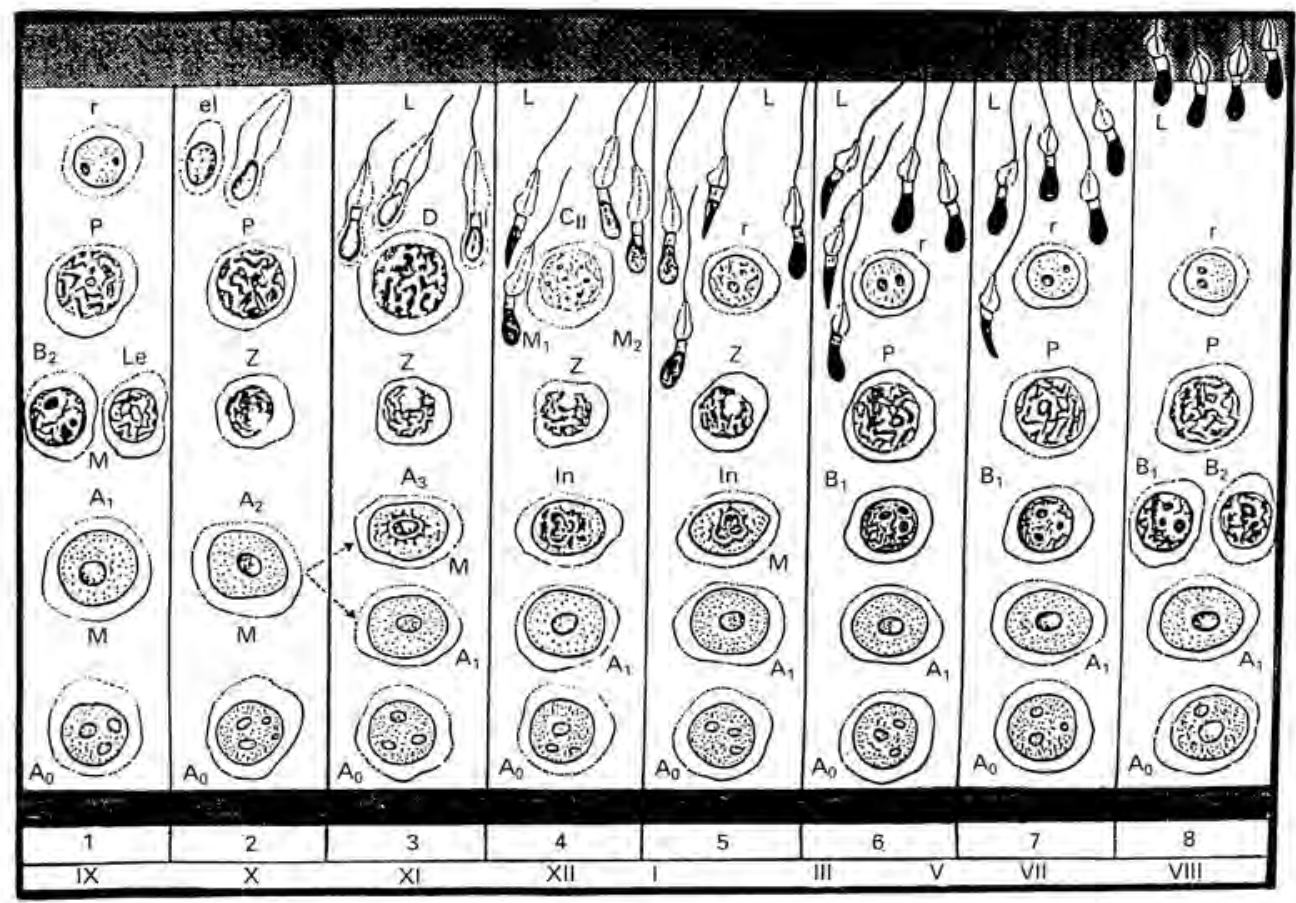

(b)

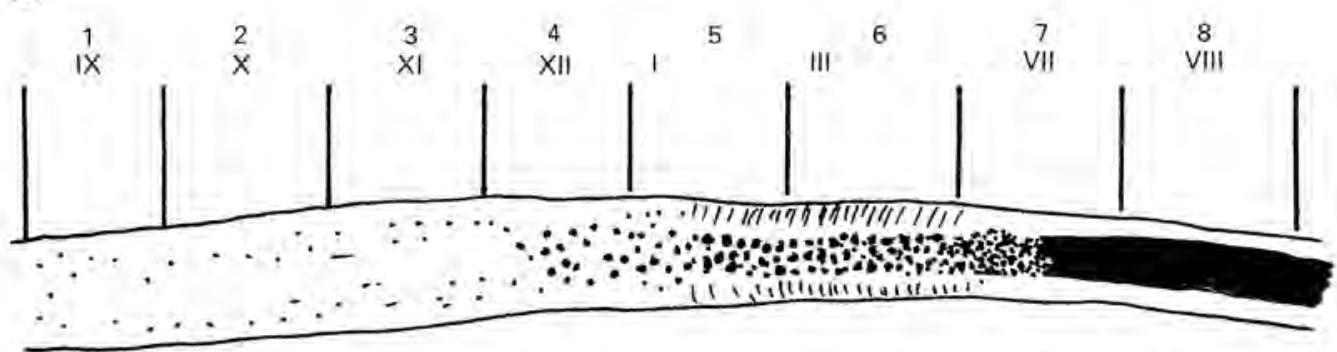

Fig. 1. (a) Diagrammatic representation of the cellular composition of the seminiferous epithelium cycle in bulls, according to the classification of Roosen-Runge and Giesel (1950; arabic numbers). Roman numerals refer to the classification of Leblond and Clermont (1952). In each column the germ cells of the cellular association are shown. $A_{0}$ and $A_{1}$ are, respectively, reserve and renewing spermatogonia; $A_{2}$ and $A_{3}$ t type $A$ spermatogonia; $\mathrm{In}$; intermediate spermatogonia; $\mathrm{B}_{1}$ and $\mathrm{B}_{2}$; type $\mathrm{B}$ spermatogonia; $\mathrm{M}$ indicates the presence of a mitotic division; Le, Z, P and D: leptotene, zygotene, pachytene and diplotene primary spermatocytes; $\mathrm{C}_{11}$ : secondary spermatocytes; $M_{1}$ and $M_{2}$ : meiotic divisions, $r$, el, and $L$ : round, elongating and elongated spermatids (from Hochereau-de Reviers et al., 1990). (b) A schematic representation of the likely transillumination profile for isolated bull seminiferous tubules with one complete wave of the seminiferous epithelium, based on published studies for the rat (see Parvinen, 1993) and the authors' unpublished observations in rams. The increased light absorption is based on the progressive condensation of the chromatin of the spermatids. Four main light absorption patterns can be recognized in the rat: pale (stages IX-XII), weak spot (XIII-I), dark spot (II-IV), and dark (VII-VIII), corresponding to stages I-3 (IX-XII), 4-5 (XII-II), 6-7 (II-VI) and 7-8 (VII-XIII) respectively, in the bull.

support for the germ cells is widely accepted. Most of the investigations of Sertoli cell regulation of germ cell development have been undertaken with isolated rat Sertoli cells cultured in vitro to allow identification of the factors produced by these cells. Cells have usually been obtained from prepubertal 
20-day-old animals. Older animals have been used but the development of Sertoli cell tight junctions and the presence of germ cells makes isolation of pure populations of viable Sertoli cells difficult from post-pubertal animals. Attempts to isolate these cells from other species, including domestic ruminants, have been limited by the extent of connective and peritubular tissues in these other species. Coombs et al. (1988) and Jenkins and Ellison (1989) have examined plasminogen activator and transferrin secretion using Sertoli cells isolated from 3-month-old Hereford bull calves, and Waites ef al. (1985) and Monet-Kuntz and Fontaine (1993) have examined protein synthesis and transferrin secretion by isolated lamb Sertoli cells cultured in vitro.

However, there are extensive changes in the Sertoli cell during postnatal and pubertal development. The blood-testis barrier is still forming at this time, the tubule lumen becomes established, production of androgen-binding protein and a number of growth factors increases markedly while inhibin, oestradiol and anti-Müllerian hormone concentrations decline (Waites et al, 1985; Gondos and Berndston, 1993). Germ cells are now considered to exert a considerable influence over adult Sertoli cell secretory activity. Thus, the validity of working with isolated, immature cells that are clearly changing their secretory profiles and which have yet to meet the full complement of germ cells that will associate with them after puberty can be questioned. Furthermore, Skinner (1993) demonstrated that the action of testosterone on Sertoli cells may be mediated in part by its actions on the peritubular cells around the base of the seminiferous tubule. These cells produce a non-mitogenic protein termed protein modulating Sertoli cells (PModS) in response to testosterone, and this protein stimulates most functions associated with differentiation of the Sertoli cell. PModS also stimulates transferrin and androgen-binding protein gene expression, and suppresses aromatase activity in Sertoli cells (Skinner, 1993).

In vivo, the Sertoli cell is highly polarized both structurally and functionally. Isolated rat Sertoli cells have been cultured on extracellular matrix components in bicameral culture chambers to maintain this polarization in vitro (see Djakiew and Onoda, 1993). With such cultures, media can be sampled from a basal compartment that might be considered to represent the interstitial compartment of the testes, and from an apical compartment that might represent the luminal compartment of the seminiferous tubule. By adding germ cells, peritubular cells, Leydig cells or putative products of these or other cells, the influence of these cells or their products on Sertoli cell secretions can be monitored. The bicameral chamber culture system has not, to our knowledge, been used with cells isolated from the testes of ruminants, but this should be tried.

The approaches outlined above have yielded a considerable amount of information about the rat Sertoli cell, and laid the foundations of our current understanding of what the Sertoli cell might use to regulate germ cell development and epithelial structure and function locally. About 100 proteins may be secreted, although less than one-third have as yet been properly identified (Jégou, 1993; Bardin et al., 1994). Factors involved in biochemical transport and protection, proteases and protease inhibitors, and basement membrane formation have been isolated, plus a plethora of hormones and growth factors (Table 1; Griswold, 1993). Specific testicular functions are yet to be determined for many of these factors, although the presence of receptors on germ cells for transferrin, insulin-like growth factor I (IGF-I), activin and stem cell factor (Pescovitz et al., 1994) lend support to the argument that such factors may be used by Sertoli cells to communicate with and thereby regulate germ cells and their development. Inhibin-related peptides appear to be significant local regulators of spermatogonial proliferation (see Moore et al, 1994 for a recent review) and IGF-I appears to stimulate premitotic DNA synthesis in rat spermatogonia and may help to maintain premeiotic DNA synthesis (Söder et al, 1992). A potent mitogenic factor has been identified in ram rete testis fluid (Brown et al., 1982), presumably from the seminiferous epithelium, but this has not been further characterized.

These results suggest that the consistent grouping of certain germ cell types at any point in the seminiferous epithelium, the different stages of spermatogenesis, occurs because the germ cells found together need similar sorts of input from their host Sertoli cell(s).

\section{Germ Cell-Sertoli Cell Interactions}

The presence of inhibin was first demonstrated in ram rete testis fluid (Setchell and Jacks, 1974) and is now widely used as a marker of Sertoli cell function. Its bi-directional secretion by Sertoli cells (through 
Table 1. Proteins secreted by Sertoli cells

\begin{tabular}{lll}
\hline Roles & Examples & Function \\
\hline Transport and bioprotection & $\begin{array}{l}\text { Transferrin } \\
\text { Androgen-binding protein }\end{array}$ & $\begin{array}{l}\text { Iron transport } \\
\text { Transport of testosterone and } \\
\text { dihydrotestosterone }\end{array}$ \\
Proteases and protease inhibitors & $\begin{array}{l}\text { Plasminogen activator } \\
\text { Cyclic protein-2/cathepsin L }\end{array}$ & $\begin{array}{l}\text { Protease } \\
\text { Protease inhibitor }\end{array}$ \\
Basement membrane & Collagen IV & Laminin \\
Hormones/growth factors & Müllerian inhibiting substance & Inhibition of Müllerian duct \\
development & Inhibition of FSH release \\
& Inhibin & Growth factor \\
\end{tabular}

Adapted from Griswold (1993).

both the basal aspect of the seminiferous epithelium into the interstitial region, and apically into the seminiferous tubule lumen) has been studied in rats. In prepubertal animals, secretion was shown to be primarily basal, towards the interstitial region, but it changed during puberty, and in mature animals most inhibin is secreted apically into the tubule lumen (Maddocks and Sharpe, 1990). The physiological approach adopted in these studies in vivo is not possible in animals such as rams or bulls because of the anatomical arrangement of the testes. However, the implication from the studies in rats is that the presence of germ cells alters the polarity of secretion of a Sertoli cell product, and this was subsequently shown to involve primarily the elongated spermatid and possibly the pachytene spermatocyte germ cells (Maddocks et al., 1992). Germ cells were implicated in the regulation of the bi-directional secretion of androgen-binding protein, with the earlier germ cells increasing basal secretion and more mature cells increasing the amount secreted apically (Morris et al., 1987). Germ cells also increase the content of mRNA encoding transferrin in rat Sertoli cells (Stallard and Griswold, 1990). Jégou et al. (1991) examined the effect of germ cells on rat Sertoli cells in culture and found that the influence of germ cells varied according to (I) the germ cell fraction tested (pachytene spermatocytes, early spermatids or residual bodies and fragments of cytoplasm from elongated spermatids); (2) the parameter of Sertoli cell function studied (for example inhibition of oestradiol, stimulation of androgen binding protein, transferrin); (3) the age of the Sertoli cell donors; and (4) the hormonal environment (in the presence or absence of FSH). They found these effects are mediated in part by a proteinaceous factor(s) detected in germ cell spent culture media, suggesting that germ cells, in conjunction with hormones such as testosterone and FSH, might regulate Sertoli cell function and spermatogenesis,

Receptors for germ cell factors such as nerve growth factor and basic fibroblast growth factor are found on Sertoli cells (Pescovitz et al., 1994). The opportunity to investigate these relationships in ruminants is again limited by the lack of experience in obtaining isolated germ cell populations with which to work. However, any model of local regulation of the testes must take into account the fact that germ cells produce specific factors to regulate Sertoli cell activity.

\section{Transilluminated dissection of staged seminiferous tubules}

In 1972, Parvinen and Vanha-Pertlula introduced the technique of transillumination-assisted microdissection of isolated rat seminiferous tubules (see Parvinen, 1993; Fig. 1). This technique allows a particular stage of the spermatogenic cycle to be determined within a given segment of tubule isolated for culture or examination in vitro. This means that it is possible to work with the intact epithelium 
containing mature Sertoli cells, a full complement of germ cells for that stage of the cycle and peritubular cells, and thereby to examine what is produced at different stages of the cycle, when production and secretion of a factor is switched on or off, and with what cellular changes this is correlated. This approach does have some limitations, requiring the isolation and dissection of the tubules and the Leydig cells are usually removed. Studies on the expression and secretion of cyclic protein-2 (CP-2), a protease inhibitor, also known as cathepsin-L, highlight the benefits of this approach. Parvinen (1993) reviewed studies by a number of groups using isolated staged rat seminiferous tubule segments, which showed stagedependent secretion of the $\mathrm{CP}-2$ protein with a peak at stages VI-VII, a similar peak in immunoreactive staining for the protein at stages VI-VII, and a peak in mRNA expression for CP-2 around stage VI. $\mathrm{CP}-2$ is now thought to play a role in spermiation, as its expression and localization are concomitant with the release of late spermatid bundles, and their movement towards the apex of the seminiferous epithelium. The isolation of staged segments of seminiferous tubules from ruminant testes would overcome many of the limitations of isolated cell preparations noted earlier. Use of enzymatic digestion has allowed for such an approach in horse testes (Johnson et al, 1990) and seminiferous tubule fragments were isolated from adult ram testes by Lok et al. (1982), although functional studies were not undertaken. These studies are necessary to ascertain the relevance or otherwise for the testes of ruminants of studies undertaken in vitro with cells from rat testes.

\section{Cell depletion studies}

Another technique that has proved very beneficial in studying interactions between germ cells and Sertoli cells in rats has been specifically to deplete certain germ cell populations in vivo. The use of localized heating of the testes $\left(43^{\circ} \mathrm{C}\right.$ for $15 \mathrm{~min}$ ) or treatment of rats with methoxy acetic acid (MAA) depletes specific germ cells in the seminiferous epithelium at the time of treatment. By a process of maturation depletion, the effect subsequently of other missing germ cell types within the epithelium can be monitored. Localized heating of the testes of ruminants is easily accomplished and both acute $\left(41-43^{\circ} \mathrm{C}\right.$ for $45-240 \mathrm{~min}$; Waites and Ortavant, 1968; Setchell et al, 1991; Hochereau-de Reviers et al, 1993) and chronic $\left(35-37^{\circ} \mathrm{C}\right.$ for $8-24 \mathrm{~h} \mathrm{day}^{-1}$ for $30-144$ days; Mieusset et al., 1991) treatments have been used to disrupt spermatogenesis reversibly by various degrees. Administration of specific chemical toxicants to ruminants to pursue similar studies is likely to be a costly exercise. Little information is available on the dose that would need to be administered, and the different ruminant digestive and metabolic processes may alter the pharmacology of the compounds used. For example, ethane dimethylsulfonate (used in rats to deplete Leydig cells specifically) when administered to pigs at the same dose per unit body mass was lethal (I. D. Morris, personal communication). Similar studies have not been undertaken in ruminants, but alternative modes of administration in ruminants (for example chronic intra-arterial infusion to the testicular artery, a technique not possible in rats) may provide opportunities for such models to be investigated further. Germ cell depletion studies in rats are reviewed by Sharpe (1993) and have led to the concept of the 'selfish germ cell', whereby each germ cell modulates functions of the Sertoli cell essential for its own survival.

As more and more factors are isolated that might be involved in the local regulation of the seminiferous epithelium, techniques such as those described above will ultimately help determine the potential significance of such factors and their specific cell associations in the testes of ruminants, and how they might function to modulate the very complex processes involved in spermatogenesis. Recent suggestions of paternal effects on embryonic development and survival (Micusset et al., 1991) emphasize the need for more information on local events regulating germ cell development and maturation.

\section{Leydig Cells and Steroidogenesis}

Testosterone is a locally produced factor known to be critical for the initiation and maintenance of spermatogenesis. Relative to the concentrations found outside the testes, high concentrations of testosterone would seem to be important within the rat testes for normal spermatogenesis (Sharpe $e t$ al., 1988; Maddocks and Sharpe, 1989a) and because it is freely diffusible, binding of androgen to albumin 
or to androgen-binding protein (ABP) may assist in its transportation and retention within the seminiferous tubule epithelium and other environments within the testes (Maddocks and Setchell, 1988). Its synthesis is primarily controlled by $\mathrm{LH}$, although a number of other factors may be involved in mediating, and perhaps refining, the actions of LH.

\section{Factors influencing Leydig cell activity}

Indirect evidence suggests that the seminiferous epithelium influences Leydig cell function. Disruption of spermatogenesis by localized heating of the testes results in both histological and functional changes in Leydig cells in rams (Setchell et al., 1991), as has been reported in rats (see Risbridger and de Kretser, 1989). In these situations, the Leydig cells appear hypertrophied and have an increased capacity to produce steroids in vitro. Local regulation is implied because such changes are confined to the damaged testes in unilaterally treated rats (see Risbridger and de Kretser, 1989). Bergh (1983) concluded that in normal rat testes, cyclic variations in Leydig cell size occur in conjunction with the phase of the spermatogenic cycle in adjacent seminiferous tubules, suggesting stage-dependent paracrine regulation of Leydig cell activity by the tubules.

The specific mechanisms involved in such regulation remain to be determined, although a number of factors from Sertoli cells have been shown to have various effects on steroidogenesis by Leydig cells. Oestradiol is produced by the Sertoli cells in immature rat testes and has an inhibitory effect on Leydig cell steroidogenesis. A testicular GnRH-like factor has been reported in the testes and in Sertoli cell culture media, and the actions of GnRH and its agonists are primarily inhibitory in most species studied (Risbridger and de Kretser, 1989). Receptors for insulin-like growth factor-I (IGF-IR) are present on Leydig cells and IGF-I and -II can stimulate LH-induced steroidogenesis in vitro (DeMellow et al, 1987). Epidermal growth factor (EGF) appears to be produced by Sertoli cells in vitro. EGF has been shown to both inhibit and stimulate steroidogenesis depending on the cell source and model used (Verhoeven and Cailleau, 1986). Transforming growth factor $\beta$ (TGF- $\beta$ ) and the related peptides, inhibin and activin, may also be involved in local regulation of steroidogenesis. Hsueh et al. (1987) reported that TGF- $\beta$ and activin inhibit steroidogenesis, whereas inhibin has a dose-dependent stimulatory effect. However, when a more highly purified Leydig cell preparation was used, activin stimulated testosterone release, an effect that could be reversed by inhibin (Moore et al., 1994). Endothelin-I (ET-I) is produced under FSH stimulation by 20-day-old Sertoli cells, and in adult rat testes high concentrations of ET-1 binding sites are found on Leydig cells (Fantoni et al., 1993). Conte et al. (1993) reported that testosterone production was increased by ET-1 even during hCG stimulation.

In addition to seminiferous tubule factors, other cells probably affect Leydig cell function. Testicular macrophages resident in the interstitial region have a close functional association with Leydig cells in rat, mouse and human testes although similar cells have not been found in the testes of rams (Pöllänen and Maddocks, 1988). Yee and Hutson (1985) reported that media from cultures of testicular macrophages stimulate Leydig cell steroidogenesis in vitro; this activity is increased if the macrophages are first stimulated with FSH. Recently we found that rat testicular macrophages produce significant amounts of prostaglandin $\mathrm{E}_{2}$ and $\mathrm{F}_{2 \alpha}$ (Kern and Maddocks, in press), which may also affect Leydig cell steroidogenesis.

Autocrine factors such as corticotrophin releasing factor (CRF) produced by Leydig cells may also contribute to this regulation, as CRF appears to inhibit testosterone biosynthesis (Matsorakos et al. 1993).

\section{Androgen action in the testes}

Germ cells, although apparently dependent upon testosterone for normal maturation, do not express androgen receptors, and the focus for most studies of androgen action within the testes has been on Sertoli cells and the peritubular cells which, in rats, do express androgen receptors. The production by peritubular cells of PModS in response to testosterone, and the influence this has on Sertoli cells has already been mentioned. Sharpe et al. (1992) identified a number of androgen-regulated proteins 
produced stage-specifically by rat Sertoli cells, and once the biology of these proteins is determined, the fundamental requirement of androgen for normal germ cell development may be understood. However, more recent evidence suggests that germ cells can respond directly to androgen via receptors for the androgen-binding protein (ABP). ABP is maximally secreted during the androgen-responsive stages of the spermatogenic cycle in rats and, in other androgen responsive tissues, cell responses to ABP differ when the ABP is complexed with testosterone (see Sharpe, 1994). Germ cells have been shown to endocytose the ABP receptor (Gérard et al., 1991) and if there is a differential response mechanism in spermatogenic cells this will lead to a new direction for the search for androgen-regulated processes within the testes. ABP is present in ram rete testis fluid, but a similar protein from the liver is found in blood (Jégou et al, 1979), a situation more comparable to that in humans, and different from rats and pigs, and there may therefore be important species differences.

\section{Local Regulation of Blood Flow and Vascular Permeability}

Changes in blood flow or vascular permeability can influence fluid volumes in the testes, and local regulation of the vasculature in the testes is implied from a number of studies, although the active factors remain to be elucidated. The capillaries of the testes have an intimate association with the avascular seminiferous tubules and in rats form a rope-ladder-like network around the tubule (Setchell et al., 1994). This structure seems ideally suited to stage-dependent regulation by the local seminiferous epithelium. A very different association is found in human testes, and the arrangement of blood vessels around the tubules also appears rather different in the testes of ruminants (Setchell et al., 1994).

Blood flow through the testis is correlated with testis mass (Setchell et al, 1994), an indirect measure of spermatogenic activity in the mature testis. After localized heating of ram testes $\left(42^{\circ} \mathrm{C}\right.$ for $45 \mathrm{~min}$ ), spermatogenesis was disrupted and testis mass and blood flow declined over the ensuing 3 weeks (Setchell et al., 1991). A similar result was observed following irradiation and immunization against $\mathrm{GnRH}$ (Setchell and Zupp, unpublished; Fig. 2). Similar studies have been reported in rats (see Setchell et al., 1994) and as recovery of the spermatogenic process repopulates the seminiferous epithelium, the increase in testis mass in this species is accompanied by an increase in testicular blood flow.

Testosterone appears to be involved in regulating fluid volumes in the testes, acting either via the Sertoli cells and peritubular cells in the seminiferous tubule, or via androgen receptors recently reported on the endothelial cells of the capillaries within the testes (Damber and Bergh, 1992). Treatment of rats with the toxin ethane dimethylsulfonate (EDS) to remove specifically Leydig cells from the testes caused a rapid reduction in interstitial fluid volumes that could be prevented by concomitant administration of testosterone, or restored subsequently by such treatment (Maddocks and Sharpe, 1989b). Using the EDS model, Collin et al. (1993) demonstrated that testosterone affects vasomotion in the testes, that is the rhythmic contractions of the microvasculature that are important in fluid exchange and thus interstitial fluid formation from blood plasma. In the absence of Leydig. cells and thus testosterone, vasomotion cannot be detected, but it returns rapidly upon re-administration of androgen (Collin et al., 1993).

Sharpe (1993) postulated a role for spermatids in influencing fluid secretions into the lumen of the seminiferous tubule, a process that is also dependent on the presence of testosterone.

Other factors are also likely to be involved in regulating blood flow and fluid exchange in the testes, but they remain to be determined. Physiological concentrations of 5-hydroxytryptamine (released/ produced by testicular nerves, mast cells and Leydig cells) and endothelin- 1 (from Sertoli cells and possibly Leydig cells) have been shown to decrease testicular blood flow in rats and may therefore play a role in controlling blood flow in the testes (Collin et al., 1994). Given the importance of maintaining sufficient blood flow through the testis, an organ that is usually almost hypoxic, further investigations of mechanisms of local regulation of the vasculature are clearly warranted. Indeed, the ram may prove to be a more appropriate model for studying the effects of vascular perturbations on function of the testes. Arterial and venous blood and lymph samples can be obtained with ease from multiple sites in both acute and chronic situations. 


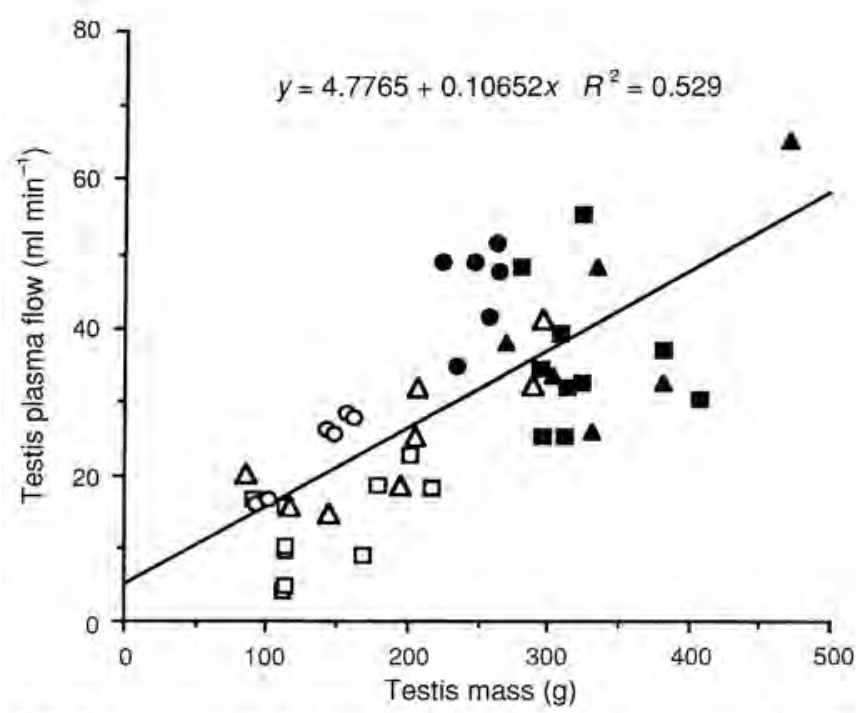

Fig. 2. The correlation between testis mass and blood plasma flow in testes of rams. Experiments were undertaken in Adelaide. South Australia with Merino rams and in Nouzilly, France with Ile de France rams during the breeding seasons. Merino rams were immunized against GnRH (Vaxtrate, Arthur Webster Pty Ltd, Baulkam Hills, NSW: 3 injections at intervals of 2 weeks) and three months later were given twice daily injections of an ovine pituitary extract (oPE) for two months to reinitiate spermatogenesis $(\Delta)$; other rams were untreated $(\boldsymbol{\Lambda})$. lle de France rams were either untreated $(\bullet)$, subjected to localized heating of the testes $\left(42-43^{\circ} \mathrm{C}\right.$ for $\left.45 \mathrm{~min}\right) 21$ days before measurement (O), surgically hypophysectomized and treated with oPE for 21 days (-) or hypophysectomized and at the same time subjected to localized heating of the testis and then treated with oPE for 21 days ( $\square$ ) (see Setchell et al., 1991 and Hochereau-de Reviers et al, 1993 for details).

\section{Cytokines and Immune Cells as Local Regulators of the Testes}

Finally, the potential significance of cytokines and the role of immune cells within the testes deserves mention. If cytokines are considered not just as modulators of the immune response per se, but also as regulators of cell division, proliferation and differentiation, it is not surprising that the rat Sertoli cell should produce cytokines such as interleukin $\mathrm{I}(\mathrm{IL}-1)$ and $\mathrm{IL}-6$, and other growth factors such as transforming growth factor $\beta$ (TGF- $\beta$ ) and insulin-like growth factor (IGF). IL- $1 \alpha$ expression in the rat testis has been found to be stage dependent and the secretion of bioactive IL-I by cultured seminiferous tubules increases in parallel with testicular maturation; IL-6 secretion increases with age and is regulated by FSH (see Jégou, 1993). There is evidence that germ cells regulate IL-I production by Sertoli cells, and residual bodies stimulate its secretion in vitro (see Jégou, 1993). However, studies with the mouse thymocyte assay did not find IL-I $\alpha$-like material in testes or in testicular lymphs of rams, bulls or pigs (B. P. Setchell, B. Fröysa, L. Plöen, O. Söder and E. M. Ritzen, unpublished).

The population of macrophages resident in the testes of a number of species has recently been studied. These cells, as mentioned earlier, have an intimate association with Leydig cells in the testes of rats, mice and humans, but in rats they appear to be downregulated in terms of their cytokine profile. Macrophages from rat testes, in contrast to peritoneal macrophages, produce little IL-1 or turnour necrosis factor $\alpha$ and do not increase their secretion of these factors in response to nonspecific immunoactive stimulation with lipopolysaccharide (LPS; Kern et al., in press). In contrast, these cells 
produce significant amounts of granulocyte-macrophage colony-stimulating factor (GM-CSF) and this is downregulated by LPS stimulation. GM-CSF has recently been implicated in tissue remodelling processes in the uterus (Robertson ef al., 1992) and the macrophages may also be involved in the testes. The significance of cytokines in regulating germ cell development is still widely underestimated. However, their importance also in modulating Sertoli cell-germ cell adhesion, and in regulating phagocytosis by Sertoli cells of residual bodies and cell debris from germ cells, is likely to be an important component of the local regulatory mechanisms within the testes.

\section{Future Directions for Research on Local Regulation of the Testes of Ruminants}

Ackland et al. (1992) indicate that the discovery of gonadal peptides can be attributed to three mechanisms: (i) factors are specifically searched for because activity is predicted by physiological experiments, (ii) failure of studies in vitro to replicate findings in vivo suggests missing signals, and (iii) immunological and molecular probes are used to search gonadal tissues for factors discovered elsewhere. Each of these series of events has been used in developing our understanding of local regulation of the testes, and the study of gene expression during spermatogenesis has provided a significant amount of information (see Means and Cruzalegui, 1993). But, as indicated throughout this paper, much of this work has been limited to work with the rat testes. Viable cell isolations from the testes of ruminants are not as easy to obtain, but the use of immunological and molecular probes is now allowing study in domestic livestock (see Ang et al, 1991) and will no doubt form the basis for most studies in the future. The use of localized heating of the testes and such manipulations to disrupt germ cell development will provide models to examine further the roles of germ cells.

\section{Conclusions}

In this review, an attempt was made to convey the complexity of what must be a very dynamic set of cellular interactions involved in local regulation of the testes. The focus for this regulation lies with the seminiferous epithelium as this tissue exerts control over the interstitial Leydig cells to regulate their production of testosterone and other factors on the vasculature to ensure delivery of oxygen and nutrients, and on the processes of cell division and multiplication within the epithelium to regulate production of spermatozoa. However, other interactions between cells within the interstitial tissue, and between these cells and the testicular vasculature are equally important and may modulate many of the endocrine activities of this tissue. The testes of ruminants offer distinct advantages over the rat testes as an experimental model when investigations and manipulations of vascular function are required. The ability to undertake chronic infusion and repetitive sampling regimens, correlated with endocrine manipulations and regular semen collection for sperm production profiles, further enhance the benefits of this model. Recent suggestions of paternal effects on embryonic development and survival emphasize the need for more information on local events regulating germ cell development and hormone secretion by the ruminant testes.

\section{References}

Ackland JF, Schwartz NB, Mayo KE and Dodson RE (1992) Nonsteroidal signals originating in the gonads Physiological Revietos $72731-787$

Ang H-L, Ungefroren H, de Bree F, Foo N-C, Carter D, Burbach JP. Ivell R and Murphy D (1991) Testicular oxytocin gene expression in seminiferous tubules of cattle and transgenic mice Endocrinology 128 2110-2117

Bardin CW, Cheng CY. Mustow NA and Gunsalus GL (1994) The Sertoli cell. In The Physiology of Reproduction (2nd Edn) pp 1291-1333. Eds E Knobil and ID Neill. Raven Press, New York
Bergh A (1983) Paracrine regulation of Leydig cells by the seminiferous tubules International Joumal of Andrology 6 $57-65$

Brown KD, Blakely DM, Henville A and Setchell BP (1982) Rete testis fluid contains a growth factor for cultured fibroblasts Biochemical and Biophysical Research Communications 105 $371-379$

Collin O, Bergh A, Damber J-E and Widmark A (1993) Control of testicular vasomotion by testosterone and tubule factors in rats Journal of Reproduction and Fertility 97 $115-121$ 
Conte D, Questino P, Fillo S, Nordio M, Isidori A and Romanelli F (1993) Endothelin stimulates testosterone secretion by rat Leydig cells Joumal of Endocrinology 136 R1-4

Coombs RJ, Ellison J. Woods A and Jenkins N (1988) Only tissue-type plasminogen activator is secreted by immature bovine Sertoli cell-enriched cultures Journal of Endocrinology $11763-67$

Damber J-E and Bergh A (1992) Editorial: testicular microcirculation - a forgotten essential in andrology? Intermational Journal of Andrology 15 285-292

DeMellow J, Handelsman DJ and Baxter R (1987) Short-term exposure to insulin-like growth factor stimulated testosterone production by testicular cells Acta Endocrinologia 115 $483-489$

Djakiew D and Onoda M (1993) Multichamber cell culture and directional secretion. In The Sertoli Cell pp 181-194 Eds LD Russell and MD Griswold. Cache River Press, Clearwater, FL

Fantoni G, Morris PL, Forti G, Vannelli GB, Orlando C, Barni T, Sestini R, Danza G and Maggi M (1993) Endothelin-1: a new autocrine/paracrine factor in rat testis American Journal of Physiology 265 E267-E274

Gérard A, Nya AE, Egloff $M$, Domingo $M$, Degrelle $H$ and Gérard H (1991) Endocytosis of human sex steroid-binding protein in monkey germ cells Amals of the New York Academy of Science 637, 258-276

Gondos B and Berndston WE (1993) Postnatal and pubertal development. In The Sertoli Cell pp 115-154 Eds LD Russell and MD Griswold. Cache River Press, Clearwater, FL

Griswold MD (1993) Protein secretion by Sertoli cells: general considerations. In The Sertoli Cell Pp 195-200 Eds LD Russell and MD Griswold. Cache River Press, Clearwater, FL

Hochereau-de Reviers M-T, Courtens I-L, Courot M and de Reviers M (1990) Spermatogenesis in mammals and birds. In Marshall's Physiology of Reproduction, Vol. 2: Reproduction in the Male PP 106-182 Ed. GE Lamming. Churchill Livingston, Edinburgh

Hochereau-de Reviers M-T, Locatelli A, Perreau C, Pisselet C and Setchell BP (1993) Effects of a single brief period of moderate heating of the testes on seminiferous tubules in hypophysectomized rams treated with pituitary extract Joumal of Reproduction and Fertility 97 381-387

Hsueh AJW, Dahl KD, Vaughan J, Tucker E, Rivier J, Bardin CW and Vale WW (1987) Heterodimers and homodimers of inhibin subunits have different paracrine action in the modulation of luteinizing hormone-stimulated androgen biosynthesis Proceedings of the National Academy of Sciences. USA $845082-5086$

Jégou B (1993) The Sertoli-germ cell communication network in mammals International Review of Cytology 147 25-96

Jégou B, Dacheux JL, Garnier DH, Terqui M, Colas G and Courot M (1979) Biochemical and physiological studies of androgen-binding protein in the reproductive tract of the man Joumal of Reproduction and Fertility 57 311-318

Jégou B, Le Magueresse B, Pineau C and Sharpe RM (1991) Germ cells and post natal development of testicular function: in vitro studies Bulletin d'Association Anatomy de Nancy 75 $33-38$

Jenkins N and Ellison J (1989) Regulation of transferrin secretion in Sertoli cells of the calf testis Animal Reproduction Science 20 II-20
Johnson L, Kattan-Said AF, Hardy VB and Scrutchfield WL. (1990) Isolation and staging of horse seminiferous tubules by transillumination Joumal of Reproduction and Fertility $\mathbf{8 9}$ 689-696

Kern S and Maddocks S Indomethacin blocks the immunosuppressive activity of rat testicular macrophages in cultures in-vitro Journal of Reproductive Immunology (in press)

Kern S, Robertson S and Maddocks S Cytokine secretion by macrophages in the rat testis Biology of Reproduction (in press)

Leblond $\mathrm{CP}$ and Clermont $\mathrm{Y}$ (1952) Spermiogenesis of rat. mouse, hamster and guinea pig as revealed by the 'periodic-acid-fuschin sulfurus acid' technique American Joumal of Analomy 90 167-215

Lok D, Weenk D and de Rooij DG (1982) Morphology, proliferation, and differentiation of undifferentiated spermatogonia in the Chinese hamster and the ram Anatomical Record 203 83-99

Maddocks S and Setchell BP (1988) The physiology of the endocrine testis Oxford Reviews of Reproductive Biology 10 $53-123$

Maddocks S and Sharpe RM. (1989a) Dynamics of testosterone secretion by the rat testis: implications for measurement of the intratesticular levels of testosterone Journal of Endocrinology $122 \quad 323-329$

Maddocks S and Sharpe RM (1989b) Interstitial fluid volume in the rat testist androgen-dependent regulation by the seminiferous tubules? Joumal of Endocrinology 120 215-222

Maddocks S and Sharpe RM (1990) The effects of sexual maturation and altered steroid synthesis on the production and route of secretion of inhibin from the rat testis Endocrinology $126 \quad 1541-1550$

Maddocks S, Kerr JB, Allenby G and Sharpe RM (1992) Evaluation of the role of germ cells in regulating the route of secretion of immunoactive inhibin from the rat testis Journal of Endocrinology $132 \quad 439-448$

Matsorakos G, Webster EL, Friedman TC and Chrousos GP (1993) Immunoreactive corticotrophin-releasing hormone and its binding sites in the rat ovary Journal of Clinical Investigation $92961-968$

Means AR and Cruzalegui F (1993) Differential gene expression from a single transcription unit during spermatogenesis Recent Progress in Hormone Research 48 79-97

Mieusset R, Quintana Casares PI, Sanchez-Partida LG, Sowerbutts SF, Zupp Л and Setchell BP (1991) The effects of moderate heating of the testes and epididymides of rams by scrotal insulation on body temperature, respiratory rate, spermatozoa output and motility, and on fertility and embryonic survival in ewes inseminated with frozen semen Annals of the New York Academy of Sciences 637 $445-458$

Monet-Kuntz C and Fontaine I (1993) Secretion of transferrin in ovine seminiferous tubule cell cultures in response to FSH: influence of breed, season of birth and age of lambs Reproduction Fertility and Development 5 83-93

Moore A, Krummen LA and Mather JP (1994) Inhibins, activins, their binding proteins and receptors: interactions underlying paracrine activity in the testis Molecular and Collular Endocrinology 100 8I-86

Morris ID, Bardin CW, Musto NA, Thau RB and Gunsalus GL (1987) Evidence suggesting that germ cells influence the bidirectional secretion of androgen binding protein by 
the seminiferous epithelium demonstrated by selective impaiment of spermatogenesis with busulphan International Joumal of Andrology $10691-700$

Parvinen M (1993) Cyclic function of Sertoli cells. In The Sertoli Cell pp 331-347 Eds LD Russell and MD Griswold. Cache River Press, Clearwater, FL

Pescovitz OH, Srivastava CH, Breyer PR and Monts BA (1994) Paracrine control of spermatogenesis Trends in Endocrinology and Metabolism 5 126-131

Pöllänen P and Maddocks S (1988) Macrophages, lymphocytes and MHC II antigen in the ram and rat testis Journal of Reproduction and Fertility $\mathbf{8 2} \quad 437-445$

Risbridger GP and de Kretser DM (1989) Paracrine regulation of the testis. In The Testis (2nd Edn) pp 255-268 Eds H Burger and D de Kretser. Raven Press, New York

Robertson SA, Brannstrom M and Seamark RF (1992) Cytokines in rodent reproduction and the cytokine-endocrine interaction Current Opinions in Inmunology 4 585-590

Roosen-Runge EC and Giesel LO (1950) Quantitative studies on spermatogenesis in the albino rat American Joumal of Anatomy 87 1-30

Setchell BP and Jacks F (1974) Inhibin-like activity in rete testis Fluid Joumal of Endocrinology 62 675-676

Setchell BP, Locatelli A, Perreau C, Pisselet C. Fontaine L, Kuntz C, Saumande J. Fontaine $\mathrm{J}$ and Hochereau-de Reviers M-T (1991) The form and function of the Leydig cells in hypophysectomized rams treated with pituitary extract when spermatogenesis is disrupted by heating the testes Joumal of Endocrinology 131 101-112

Setchell BP, Maddocks S and Brooks DE (1994) Anatomy. vasculature, innervation and fluids of the male reproductive tract. In The Plusiology of Reproduction (2nd Edn) pp 1063-1175 Eds E Knobil and JD Neill. Raven Press, New York

Sharpe RM (1993) Experimental evidence for Sertoli-germ cell and Sertoli-Leydig cell interactions. In The Sertoli Cell pp 391-418 Eds LD Russell and MD Griswold. Cache River Press, Clearwater, FL
Sharpe RM (1994) Regulation of spermatogenesis. In The Physiology of Reproduction (2nd Edn) PP 1363-1434 Eds E Knobil and JD Neill. Raven Press, New York

Sharpe RM, Donachie K and Cooper I (1988) Re-evaluation of the intratesticular levels of testosterone required for quantitative maintenance of spermatogenesis in the rat Journal of Endocrinology 117 19-26

Sharpe RM, Maddocks S, Millar M, Kerr JB, Saunders PTK and McKinnell C (1992) Testosterone and spermatogenesis: identification of stage-specific, androgen-regulated proteins secreted by adult rat seminiferous tubules Journal of Andrology 13 172-184

Skinner MK (1993) Sertoli cell-peritubular myoid cell interactions. In The Serfoli Cell pp 477-483 Eds LD Russell and MD Griswold. Cache River Press, Clearwater, FL.

Söder O, Bang P, Wahab A and Parvinen M (1992) Insulin-like growth factors selectively stimulate spermatogonial, but not meiotic, deoxyribonudeic acid synthesis during rat spermatogenesis Endocrinology 131 2344-2350

Stallard BJ and Griswold MD (1990) Germ cell regulation of Sertoli cell transferrin mRNA levels Molecular Endocrinology 4 393-401

Verhoeven G and Cailleau J (1986) Stimulatory effects of epidermal growth factor on steroidogenesis in Leydig cells Molecular and Cellular Endocrinology 47 99-106

Waites GMH and Ortavant R (1968) Effects précoces d'une brève elevation de la temperature testiculaire sur la spermatogenèse du bélièr Annales de Biologie Animale, Biochemie et Biophysique 8 323-331

Waites GMH, Speight AC and Jenkins N (1985) The functional maturation of the Sertoli cell and Leydig cell in the mammalian testis Journal of Reproduction and Ferility 75 $317-326$

Yee JB and Hutson JC (1985) Effects of testicular macrophageconditioned medium on Leydig cells in culture Endocrinology 116 2682-2684 